\title{
IMPLIKASI APLIKASI PEMBACA BUKU DALAM MENINGKATKAN LITERASI TUNANETRA
}

\section{Rd. Muhammad Fathurahmat}

\author{
Program Studi Pendidikan Masyarakat IKIP Siliwangi, Cimahi, Jawa Barat, Indonesia \\ muhammadfathurahmat@gmail.com
}

Received: October, 2020; Accepted: January, 2021

\begin{abstract}
Blind people in carrying out various activities, especially book reader applications, which are very helpful in making it easy to get information and knowledge. The purpose of this study was to analyze how effective the book reader application is in helping the blind in DPC PERTUNI Sumedang in improving and maintaining literacy culture. The theoretical basis used in this research is literacy theory, braille and talkback. The method used in this research is a qualitative descriptive approach, with interview techniques and case studies. The conclusion of this study, proves that with the book reader application, blind people who are members of the DPC PERTUNI Sumedang are helped in creating in the field of literacy..
\end{abstract}

Keywords: book reader application, improve literacy

\begin{abstract}
Abstrak
Tunanetra dalam melakukan berbagai aktivitasnya, terutama aplikasi pembaca buku yang sangat membantu memberikan kemudahan untuk mendapatkan informasi dan ilmu pengetahuan. Tujuan penelitian ini adalah untuk menganalisis seberapa efektifnya aplikasi pembaca buku yang membantu tunanetra di DPC PERTUNI Sumedang dalam meningkatkan dan menjaga budaya literasi. Landasan teori yang digunakan dalam penelitian ini adalah teori literasi, braille dan talkback. Metode dalam penelitian ini yang digunakan yaitu pendekatan deskritif kualitatif, dengan teknik wawancara dan studi kasus. Kesimpulan penelitian ini, membuktikan dengan adanya aplikasi pembaca buku, para tunanetra yang tergabung dalam organisasi DPC PERTUNI Sumedang terbantu dalam berkreasi di bidang literasi.
\end{abstract}

Kata Kunci: aplikasi pembaca buku, meningkatkan literasi

How to Cite: Fathurahmat. (2021). Implikasi Aplikasi Pembaca Buku Dalam Meningkatkan Literasi Tunanetra. Comm-Edu (Community Education Journal) 4 (1), 1-5.

\section{PENDAHULUAN}

Dalam merealisasikan salah satu poin pada pembukaan Undang-Undang Dasar 1945. Di Alenia keempat yang berbunyi "mencerdaskan kehidupan bangsa". Maka dari itu menjaga budaya literasi merupakan salah satu cara dan sebuah kewajiban bagi semua orang termasuk para tunanetra agar poin tersebut dapat terealisasikan, namun ada kendala bagi sebagian besar para tunanetra tatkala membaca maupun menulis karena mereka mesti menggunakan sistem tulisan braille. Dimana sistem tulisan braille harus memiliki keterampilan khusus dan tidak fleksibel, sehingga menimbulkan rasa malas untuk menjaga budaya literasi.

Dengan perkembangan era globalisasi, banyak inovasi-inovasi dilakukan di segala bidang,termasuk dunia teknologi. Selain itu dalam dunia teknologi sudah memulai berinovasi membuat hadware maupun sofware (aplikasi) yang dapat membantu, meringankan khususnya para tunanetra menjalankan aktivitasnya, terutama berkegiatan membaca dan menulis. Para tunanetra dalam melakukan kegiatan membaca maupun menulis menggunakan hadware 
berbasis android yang dilengkapi dengan sofware (aplikasi) pendukung yaitu Talk Back (screen reader), Envision AI dan sejenisnya, yang mana pola kerjanya mengkonversi teks to voice.

Tunanetra adalah individu yang memiliki hambatan dalam penglihatan, baik yang memiliki penglihatan lemah atau akurasi penglihatan kurang dari 6/60 setelah dikoreksi atau tidak lagi memiliki penglihatan. Orang yang mengalami gangguan penglihatan dapat diketahui dengan kondisi sebagai berikut: (a) ketajaman penglihatannya kurang dari ketajaman yang dimiliki orang awas; (b) terjadi kekeruhan pada lensa mata atau terdapat cairan tertentu; (c) posisi mata sulit dikendalikan saraf otak; dan (d) terjadi kerusakan susunan saraf otak yang berhubungan dengan penglihatan. Serta (e) terjadinya seseorang, menjadi seorang tunanetra disebabkan oleh beberapa faktor yaitu dapat disebabkan oleh faktor keturunan (gen), penyakit, dan kecelakaan baik sedang berkerja, berkendara, dan sebagainya (Sholeh, 2016).

Talk Back adalah Talk berarti Berbicara dan back artinya kembali atau dalam konteks ini adalah mengulang kembali. Aplikasi ini memiliki fitur yang di rancang khusus untuk pengguna android yang memiliki keterbatasan pengelihatan misalkan mata min atau plus, silinder atau gangguan pengelihatan lainya. Fungsi utama aplikasi ini adalah mengucapkan semua yang kita lakukan di ponsel android, misalkan sedang mengetikkan nama, masuk ke menu, setting, membuka aplikasi dan lain lain. Aplikasi TalkBack ini, dibuat untuk mempermudah para penderita kelainan penglihatan atau tunanetra agar dapat menggunakan smartphone android yang kebanyakan memiliki layar sentuh yang dimana para penyandang tunanetra akan lebih kesulitan dalam penggunaannya jika dibandingkan dengan handphone yang memiliki papan tombol (Herwanto, Saviku, \& Dai, 2019).

\section{METODE}

Metode penelitian menggunakan pendekatan kualitatif dengan metode deskriptif. Metode ini dipilih karena data yang dkumpulkan dalam penelitian ini berupa penjabaran yang diuraikan dengan kata-kata. Penelitian ini juga bermaksud untuk memahami, mengungkap dan menjelaskan berbagai gambaran atas beberapa fenomena-fenomena yang ada di lapangan dan kemudian dirangkum menjadi kesimpulan deskriptif berdasarkan data dari hasil penelitian yang dikumpulkan sendiri oleh peneliti. Salah satu ciri dari penelitian kualitatif adalah deskriptif, data yang dikumpulkan berupa penjabaran yang diuraikan dengan kata-kata dan gambar (Azzahro \& Kurniadi, 2017).

Sedangkan instrument penelitian yang digunakan dalam penelitian ini sebagai berikut:

Pertama, studi dokumentasi adalah sebuah dokumen yang di dalamnya ada catatan peristiwa yang sudah berlalu. Dokumen bisa berbentuk tulisan, gambar atau karya-karya monumental dari seseorang, dokumen yang berbentuk tulisan msalnya catatan harian, sejarah kehidupan (life histories), ceritera, bografi, peraturan, kebijakan. Dokumen yang berbentuk gambar misalnya foto, gambar hidup, sketsa dan lain-lain. Dokumen yang berbentuk karya misalnya karya seni, yang dapat berupa gambar, patung, film dan lain-lain (Sugiyono, 2018).

Kedua, wawancara adalah pertemuan dua orang untuk bertukar informasi dan ide melalui tanya jawab, sehingga dapat dikontruksikan makna dalam sebuah topik tertentu (Sugiyono, 2018). 
Objek penelitian pada saat pengumpulan data melalui wawancara dengan anggota sejumlah 2 orang dan 1 orang pengurus organisasi DPC PERTUNI (dewan pengurus cabang persatuan tunanetra Indonesia) Kabupaten Sumedang, Jawa Barat.

\section{HASIL DAN PEMBAHASAN}

\section{Hasil}

Begitu juga dengan para tunanetra salah satunya meiliki kemampuan menulis dan membaca, menggunakan metode tulisan Braille. Braille adalah sejenis sistem tulisan sentuh yang digunakan oleh penyandang tunanetra. Sistem ini diciptakan oleh seorang Perancis yang bernama Louis Braille yang mengalami hilangnya penglihatan disebabkan kebutaan waktu kecil, tulisan ini dinamakan huruf Braille. Melalui perjalanan yang panjang, tulisan Braille sekarang telah diakui efektifitasnya dan diterima sebagai tulisan yang digunakan oleh tunanetra di seluruh dunia. Selain itu huruf Braille bukan saja sebagai alat komunikasi bagi para tunanetra tetapi juga sebagai representasi suatu kompetensi, kemandirian, dan juga persamaan (Herwanto, Saviku, \& Dai, 2019).

Seiring perkembangan zaman, perubahan demi perubahan terus terrjadi dalam kehidupan, termasuk dunia teknologi yang memanjakan penggunanya dengan fitur-fitur yang dapat membantu dan memudahkan penggunanya, terutama bagi para tunanetra dengan berkembangnya teknologi, keberlangsungan aktivitasnya sangat terbantu, khususnya dalam berkegiatan menulis dan membaca. Karena adanya vitur yang diciptakan dalam hadware berbasis android, dimana sebagian besar tunanetra menggunakannya. fitur tersebut yaitu TalkBack, sesuai namanya Talk berarti Berbicara dan back artinya kembali atau dalam konteks ini adalah mengulang kembali. Aplikasi ini memiliki fitur yang di rancang khusus untuk pengguna android yang memiliki keterbatasan pengelihatan misalkan mata min atau plus, silinder atau gangguan pengelihatan lainya. fungsi utama aplikasi ini adalah mengucapkan semua yang kita lakukan di ponsel android, misalkan sedang mengetikkan nama, masuk ke menu, setting, membuka aplikasi dan lain lain . Aplikasi TalkBack ini, dibuat untuk mempermudah para penderita kelainan penglihatan atau tunanetra agar dapat menggunakan smartphone android yang kebanyakan memiliki layar sentuh yang dimana para penyandang tunanetra akan lebih kesulitan dalam penggunaannya jika dibandingkan dengan handphone yang memiliki papan tombol. Dan dapat dilengkapi dengan aplikasi pendukung yaitu Envision AI serta sejenisnya, merupakan Aplikasi pembaca buku adalah sebuah perangkat lunak yang dapat mengambil gambar berupa teks atau tulisan menggunakan kamera, lalu di konversikan menjadi voice. Selain dapat mengkonversikan dari gambar berupa teks/tulisan to voice, aplikasi pembaca buku juga dapat mengkonversikan teks atau tulisan dalam bentuk extensi docx, txt, pdf dan sebagainya to voice. 


\section{Pembahasan}

Berdasarkan hasil wawancara dengan anggota dan pengurus organisasi DPC PERTUNI (dewan pengurus cabang persatuan tunanetra Indonesia), di Kabupaten Sumedang, Jawa Barat.

Menurut pengurus PERTUNI D. T. : sebagai penyandang tunanetra sejak lahir, ia merasa kemampuan dalam menulis dan membaca menggunakan metode braille sudah cukup terbantu, namun setelah adanya teknologi yang dapat membantu tunanetra khususnya dalam menulis dan membaca, ia merasa lebih terbantu karena terbatasnya informasi maupun ilmu pengetahuan yang disajikan dalam bentuk tulisan braille, dan sulitnya mendapatkan majalah dan buku braille, tidak mudah dicari di toko-toko buku, harus melalui lembaga atau organisasi tunanetra dengan prosedur-prosedur yang mesti dijalani untuk mendapatkannya.

Mnurut anggota PERTUNI E. B. R. : kemampuannya dalam menulis dan membaca menggunakan metode braille sangatlah kurang, karena ia dari sejak kecil sudah terbiasa menulis dan membaca menggunakan tulisan non braille, namun takdir berkata lain disaat ia beranjak remaja harus menerima hilangnya penglihatan yang disebabkan sakit. Dari situ ia mau tidak mau harus mempelajari tulisan braille, dimana ketika membaca ataupun menulis harus memiliki ketrampilan tangan yang lebih, agar peka pada tulisan braille. Tetapi ia merasa terbantu dengan perkembangan teknologi sperti sekarang ini, sehingga ia dapat menulis dengan mudah, membaca informasi atau ilmu pengetahuan dengan mudah untuk mencarinya.

Menurut anggota PERTUNI P. K. P. : kelebihan dan kekurangan tulisan braille yaitu dapat mengasah kemampuan indra perabaan sedangkan kekurangannya. kurangnya informasi atau ilmu pengetahuan yang di sajikan, terlebih ia sekarang sebagai mahasiswa merasa tidak ada buku yang menunjang perkuliahan, tetapi dengan adanya teknologi ia merasa terbantu, khususnya dalam menunjang perkulihan, sehingga ia dapat meningkatkan dalam menulis dan membaca.

\section{KESIMPULAN}

Berdasarkan hasil penilitian kepada anggota dan pengurus DPC PERTUNI Sumedang disimpulkan sebagai berikut :

Dalam melakukan berkegiatan membaca maupun menulis menggunakan metode tulisan braille sangatlah penting untuk para tunanetra, karena dengan membaca ataupun menulis menggunakan braille dapat melatih motorik indra peraba agar dapat mudah peka terhadap benda-benda yang dipegangnya hingga mengenalinya, dan tulisan braille tidak bisa dilupakan maupun dimusnahkan dikarenakan bagian dari identitas sebagai tunanetra. Namun tidak dapat bergantung sepenuhnya pada tulisan braille untuk mencari informasi, ilmu pengetahuan dan lain-lain, karena terbatasnya informasi, ilmu pengetahuan dan lain-lain, yang disajikan dalam bentuk tulisan braille sehingga mesti bisa bertransformasi pada teknologi, terlebih pada aplikasi pembaca buku dalam meningkatkan literasi.

\section{DAFTAR PUSTAKA}

Azzahro, A., \& Kurniadi, D. (2017). Penggunaan Tongkat pada Siswa Tunanetra SMALB dalam Melakukan Mobilitas. Jassi_anakku, Volume 18 No. 1, 19-25. 
Gitardiana, H. U., \& Namawi, A. (2017). Pelaksanaan Pelatihan Keterampilan Tata Cara Makan dan Minum bagi Anak Tunanetra dengan Disabilitas Tambahan (Studi Desktiptif Kualitatif pada Anak Tunanetra dengan Disabilitas Tambahan di PSBN Wyata Guna Kota Bandung). Jassi_anakku, Volume 18 No.1, 33-34.

Herwanto, F., Saviku, S. A., \& Dai, M. (2019). Aplikasi Pembaca Tunanetra menggunakan Smartphone Android. Jurnal JTII, Volume 4 No. 1.

Justicia, L. T., Tolle, H., \& Amalia, F. (2017). Rancang Bangun Aplikasi Messaging Berbasis Voice Interaction Bagi Penderita Tunanetra Pada Sistem Operasi Android. Jurnal Pengembangan Teknologi Informasi dan Ilmu Komunikasi, Volume 1 No. 7.

Priyadi, E. (2014). Analisis Aplikasi Talkback Bagi Penyandang Tunanetra Pada Operasi Sistem Android. Jurnal Penelitian.

Sholeh, A. (2016). Aksesibilitas Penyandang Disabilitas terhadap Perguruan Tinggi: Studi Kasus di Empat Perguruan Tinggi Negeri di Yogyakarta. Yogyakarta: LKIS Printing.

Somantri, T. S. (2007). Psikolog Anak Luar Biasa. Bandung: Refka Aditama.

Sugiyono. (2018). Metode Penelitian Kuantitatif, Kualitatif, dan R\&D. Bandung: Alfabeta, cv.

Umami, A. S., \& Andajani, S. J. (2017). Studi Deskriptif Teknik Penguasaan Kemampuan Orientasi dan Mobilitas menggunakan Smartphone Berbasis Android Siswa Tunanetra. Jurnal Pendidikan Khusus. 